\title{
COPING STRATEGIES TO CLIMATE CHANGE THROUGH INDIGENOUS TECHNOLOGY KNOWLEDGE IN AGRICULTURE
}

\author{
DEEPAK RAJ PARAJULI \& PRATAP MAHARJAN
}

Excerpt of the Research Submitted to obtain Masters of Philosophy,

Development Studies, Kathmandu University, Nepal

\begin{abstract}
Climate change is accepted as the greatest environmental and social threats to human civilization at present. We primarily examined the role of Indigenous Technology Knowledge (ITK) in adapting to the impacts of climate change. To carry out this research at Sahartara VDC of Dolpa district, Nepal, we have used mixed research method (Survey and Ethnography). Mann Kendal Test verified that rainfall of the area had been decreased by 1.254 mm every year from 1984-2012 while minimum temperature is increasing and maximum Temperature is decreasing from 1991 to 2013, which is a sign of change in climate variability. Moreover, people have experienced the gradual rise in temperature for a decade and facing erratic and unprecedented rainfall over the same period. Their traditional methods of terrace farming, leaving crop residue and fallow land is aiding them to protect the land from erosion and landslide along with maintaining soil fertility. Practices such as managing crop timing, selection of the more resilient crops, crop rotation, and intercropping are helping them to fight against the food insecurity likely to be induced by climate change by ensuring at least yield of one crop, controlling pest and maintaining the production. People exchange the seeds within the community protecting the gene pool of the community. We believe their major strength is the use of the traditional variety of crops, which has already adapted to the nature. We deem that these efforts have helped people to adjust to the changing environment.
\end{abstract}

KEYWORDS: Climate Change, Indigenous Technology, Knowledge and Agriculture

Received: Aug 08, 2017; Accepted: Aug 28, 2017; Published: Sep 11, 2017; Paper Id.: IJASROCT201721

\section{INTRODUCTION}

Nepal is an agrarian country, where the majority of the population depends upon subsistence agriculture. In addition, Nepal is rich in both ethnic and biological diversity. Agriculture, depends upon biophysical and geochemical characteristics of the region, so, within the slight increase of the altitude; climatic patterns are changed, leading towards the existence of unique biological resources with varieties and on the other different ethnic diversities, from one region of the country to another area. This regional variation in climatic conditions, harbors a unique biological resource that provides the broad range of ecosystem, goods and services to local communities. The dramatic yet swift change in climatic condition, has equipped the local people with the resource management knowledge, which has been passed from one generation to another and refined through time.

Intergovernmental Panel on Climate Change [IPCC] (2007) report states that, Climate Change (CC) is already having discernible impacts, particularly in least developed countries like Nepal, that are more vulnerable from the effects because of their inability to cope with these climatic shocks. As food supply depends on agricultural productivity, which in turn is affected by changes in climate for instance temperature and rainfall. "Climate change will directly affect crop yield because of alterations in temperature, and indirectly through 
changes in soil quality, pest, and diseases" (Explore, 2005, as cited in Agbola \& Ojeleye, 2007). Even small changes in climatic conditions affect largely, on people's lives. The change in climatic pattern, such as rainfall and temperature rise has increased the farmer's production risks, in the agriculture sector. The changing climate has delayed the monsoon, exposing most suitable land barren and decrement in agricultural productivity (Regmi \& Adhikari, 2007).

As dramatic yet, swift variation in climatic condition has equipped the local, with the resource management knowledge, that has been passed from one generation to another and refined through time, the ethnic communities are utilizing such indigenous technical knowledge (ITK) for their survival for centuries. Indigenous people live symbiotically with ecosystems and possess varieties of knowledge, and skills necessary for wise use of natural resources. "Moreover, these techniques are environmentally sound, socially accepted, contribute to biodiversity conservation, and sustain agriculture in harmony with nature" (Sharma, Sitaula, \& Bajaracharya, 2009, p. 570). Thus, it is imperative to document this knowledge, not only for transferring between ecologically similar regions, but also to aid scientists and natural resource managers, in developing context and region specific solutions to agricultural problems. Hence, through this study, I wanted to explore how the ITK is contributing to adapt to the changing climate and their effectiveness, in the agriculture sector.

\section{PROBLEM STATEMENT}

Anthropogenic activities increase greenhouse gases in the atmosphere, which in turn enhances the temperature of the earth, thereby, changing the climatic variables such as temperature and precipitation. The increase in temperature and change in the rainfall pattern has both direct and indirect impacts, on the agriculture pattern and production (Regmi \& Adhikary, 2007). Furthermore, increase in temperature increases the water demand of the crop as the moisture evaporates, due to increased temperature. The increase in the microbial action with an increase in temperature will lead to decrease in the soil organic carbon and other micro nutrients necessary, which affects the soil fertility (Malla, 2008). Nepal ranks the fourth most vulnerable countries in the world, by Maplecroft - a British organization based on its growing vulnerability to climate change impacts (Maplecroft, 2011). With the low coping capacity, the effects of the climate change hit hard to the poor, marginalized groups of the population and farmers, who are dependent directly on the natural resources for their livelihood. The modification of the climatic parameters affects the crop cycle, production and decreases the nutrient content, which could lead to the food insecurity and one of the leading causes of the hunger problem in the long run (Malla, 2008). The farmers are the frontier and immediate response of the climate change impacts. They have adapted to amend the climate in the past, through the adoption of "Indigenous Knowledge" (IK) (Parajuli \& Das, 2013) to safeguard their crops and sustained their livelihood (Chhetry \& Belbahri, 2009; Branca, McCarthy, Lipper, \& Jolejole, 2011).

\section{PURPOSE OF THE STUDY}

The principal objective of this research was to explore the current ITK, in agricultural practices in Shaartara VDC of Dolpa, Nepal and to establish the linkages of ITK with climate change and check whether those actual ITK was contributing to adaptation, to climate change in agriculture. Our primary research question was; what different types of Indigenous Technology Knowledge (ITK) do rural farmers select to changing the climate?

\section{LITERATURE REVIEW}

\section{Climate Change in Nepal}

Being one of the most diverse countries concerning Geophysical and climatic conditions, effects of CC can be 
observed in different places and different regions in variable conditions. The different climatic variability in different areas of Nepal can be observed mainly in changes in temperature, precipitation pattern, increases in extreme weather events, melting of glaciers, etc. This erratic change in climate has triggered most of the negative (including few positives such as the increase in temperature in higher altitude making space to grow lower altitude's crops/trees) effects. Contrary, includes effects like the decrease in agricultural activities, increase in diseases and pests, reduced soil fertility, and so forth.

Regarding temperature, according to the study, which has conducted by OECD (2003), projected future scenario of mean annual temperature, which would increase by an average of 1.2 degree Celsius by 2030, 1.7 degree Celsius by 2050 and 3 degree Celsius by 2100 (as cited in Timsina, 2011). With the given values for temperature increase, different studies have presented different data. Another study was done by NCVST (2009), using Global Circulation Model (GCM) and Regional Circulation Model (RCM) projects; "the mean annual temperature increase by 1.4 degree Celsius by 2030, 2.8 degree Celsius by 2060 and 4.7 degree Celsius by 2090" (as cited in Timsina, 2011). Despite various inconsistencies, prevalent in the data about projected temperature increase, there is no room for doubt that temperature is rising at a precarious rate, and Nepal will be much affected by this increase in comparison to other areas. Quadir et al.'s (2004) study carried around the Bay of Bengal, from Nepal in a north to Malaysia, showed the increase in temperature is more predominant in Nepal, in comparison to other countries (as cited in Khatiwada, 2011, p. 8). Figure 1 below, depicts the trend of average maximum temperature in Nepal.

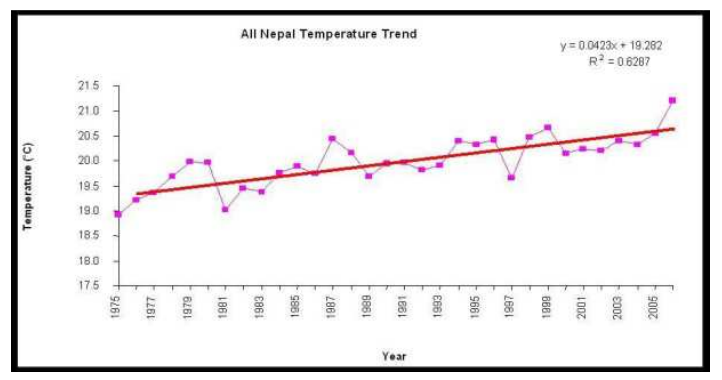

Figure 1: The Trend of Average Annual Max, the Temperature of Nepal (1975-2006)

(Source: Baidya \& Karmacharya, 2007; as Cited in Malla, 2008)

The trend in the above figure shows, "Nepal's temperature has increased by $1.8^{\circ} \mathrm{C}$, during the last 32 years and the average temperature increase was recorded as $0.06^{\circ} \mathrm{C}$, per year (Shrestha et al., 1999, as cited in Malla, 2008). Interestingly, temperature variability is found distinct in the different region of the country itself. There is found to be a great increase in temperature in a Himalayan region, than other areas of the country. Shrestha et al., 1999, reported, "Average temperature increase in Terai and Himalayas, as $0.04^{\circ} \mathrm{C}$ and $0.08^{\circ} \mathrm{C} /$ year, respectively" (Shrestha et al., 1999, as cited in Malla 2008). The reason behind it is explained by snow melting in the region, and solar radiation absorbed by both glacial lakes and land. Similarly, spatial distribution, the NCVST (2009) study showed a higher increment in temperature, over the western and central region as compared to eastern Nepal, for the year 2030, 2060 and 2090 (as cited in Timisina, 2011). 


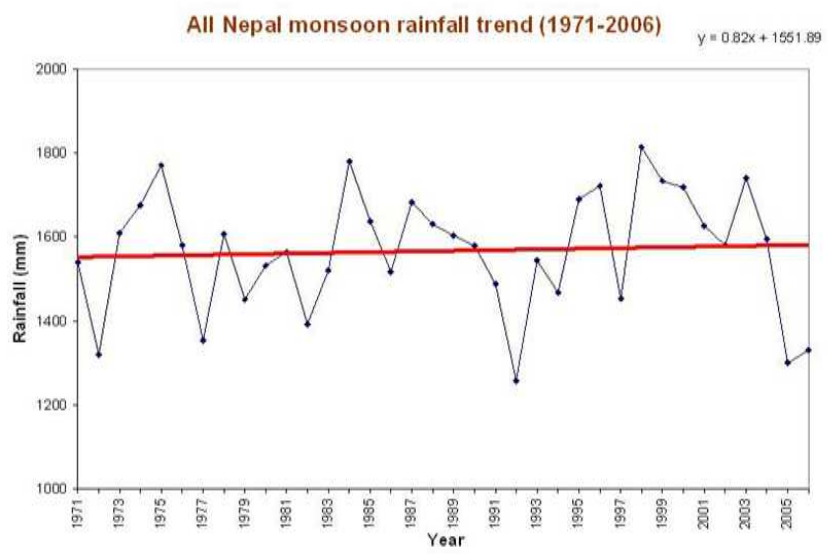

Figure 2: Trend of Total Precipitation of Nepal

Similarly, analysis of the trend of average rainfall in Nepal showed an erratic pattern of precipitation in the country. There is found to be an unusual pattern, sometimes with higher intensity of precipitation, but less number of rainy days and sometimes-unusual rain, with no decrease in total amount of annual precipitation has been experienced. These events have ameliorated possibility of climatic extremes, like irregular monsoon pattern, droughts, and floods.

Similar to temperature, a variable of rainfall pattern is observed differently, in respect to different regions of Nepal. Baidya et al. 2008, reported, "Increasing trend in precipitation in places below 1500m elevation while decreasing trend above 1500m" (as cited in Khatiwada, 2011). Projection of winter rainfall reflects no change in precipitation in western Nepal, whereas, there is up to 5-10\% increase in eastern Nepal (Timisina, 2011). Moreover, variability in precipitation pattern with frequently observed increment, in a monsoon and post monsoon rainfall, and alike future projection (as presented in the table below) has become biggest concern for all.

Table 1: Precipitation Projection for Nepal

\begin{tabular}{|c|c|c|c|c|}
\hline Year & \multicolumn{2}{|c|}{ Annual Mean } & \multicolumn{2}{c|}{ Monsoon Rainfall } \\
\hline & Multi-Model Mean & Range & Multi-Model Mean & Range \\
\hline $2030 \mathrm{~s}$ & $+0 \%$ & $-34-+22 \%$ & $+2 \%$ & $-40-+143 \%$ \\
\hline $2060 \mathrm{~s}$ & $+4 \%$ & $-36-+67 \%$ & $+7 \%$ & $-40-+143 \%$ \\
\hline $2090 \mathrm{~s}$ & $+8 \%$ & $-43-+80 \%$ & $+16 \%$ & $-52-+135 \%$ \\
\hline
\end{tabular}

Source: (GoN, 2011, as cited in Timsina, 2011)

With the complex topography and climatic variation in short distances, Nepal ranks as the fourth most vulnerable country to climate change (Maplecroft, 2011). The severity reaches its height, because of its low-level development with weak plans and mechanism. However, the context of vulnerability differs according to the different factors and conditions, observed impacts seem to be severe in every context. The observed results, along with projected changes are likely to have impacts on various sectors of Nepal, with some sector having less impact and some relatively more. Some of the sensitive areas, as pointed by Timsina (2011) are "agriculture, forestry, water and energy, health, infrastructure, tourism, industry"). More or less, it is overt that CC impact, more to the area more which is related to directly livelihoods and economy of the people, agriculture being one of them.

\section{Climate Change Adaptation}

The concept of adaptation is not new, and it has been practiced for generations. Adaptation ranges from simple measures like indigenous knowledge and skill adopted, to high invested required technologies and competencies, adopted 
by the farmers to minimize the effects brought by the climate change in the farming practices. In simple, it can be referred to as such strategies that will enable people or community to take appropriate actions for anticipated or projected changes in climate change. IPCC (2001) has reported these plans, as the response for either to reduce its adverse effects or to take advantage, offered by such response (as cited in Fransciso, 2008). Therefore, if the appropriate action with proper planning is taken into consideration to minimize the damage, it can save money and lives, and can create more opportunities that will serve as an advantage.

\section{CONCEPTUALIZING INDIGENOUS KNOWLEDGE}

Indigenous traditional knowledge is knowledge, which exists, in our local community and societies from the time immemorial (Sharma et al., 2009).The knowledge that is used by the people (we call them first settlers), who were living there for a long time and are very close to nature (river, land, and forest). Any ethnic groups who have historically, belonged to a particular region or country, and may have different often-unique cultural, linguistic, traditional, and other characteristics, to those of the dominant culture of that region are regarded as indigenous people (Shrestha et al., 2008). In other words, their life is spent in the proximity of nature and has a unique system of life, i.e. self-created or without borrowing from others, can be called as Indigenous Knowledge. It is the local knowledge, which is exclusive to a given culture or society. It can also be defined as local knowledge, held by indigenous people, or local knowledge unique to a given culture or society (Berkes 1999, as cited in ICIMOD, 2007).

It is different from the knowledge, generated by the national and international research institute. It is the basis for local-level decision making in agriculture, health care, food preparation, education, natural-resource management, and a host of other activities in rural communities (Warren, 1991, as cited in Parajuli \& Das, 2013). Indigenous people, without having support from others, decide how to use the resources that are derived from nature, for their survival. Indigenous knowledge is the information, that people in a given community, based on experience and adapt to local culture and environment, have developed over time, and continued to improvise and develop (Shrestha et al., 2008). Thus, we can say indigenous knowledge has its base on the unique sense of life, or the single system of articulation and is the manifestation of the culture which is not borrowed from others. They have used their knowledge, to survive even in the harsh environmental conditions. Exchanging of seeds among the community people, conservation of traditional varieties of seeds, storing the quality seeds in separate places for next seasons are some instances of the existence of indigenous knowledge, in the community.

\section{Indigenous Technology Knowledge (ITK) in Agriculture}

Indigenous knowledge is part of the life of the rural poor, because their livelihood depends almost entirely on specific skills and knowledge, for their survival. This kind of experience is closely related to the survival and subsistence of the local communities, offers the boundless potential for the increase in agriculture production to tackle the problem of food insecurity (Abioye, Zaid, \& Egberongbe, 2011). In the areas of semi-commercialized farming, farmers is injudiciously using various pesticides for an increased productivity and risk mitigation in crop production, even though, an average application rate of $142 \mathrm{~g} / \mathrm{ha}$ (Adhikari, 2002, as cited in Ghimire, 2008) and annual consumption of pesticides in Nepal is not considered high. This farming, with no or moderate use of Agrochemicals becomes a strategic destination, towards achieving sustainable development of Nepalese agribusinesses (ibid.). 
The food insecurity well-recognized impact of climate change could thus be reduced by integration of Indigenous knowledge, with the modern agricultural practices. The IK differs from community to community, and so does its technologies and usage. There is still much-undocumented knowledge that might be still practiced in some communities. Wherever they are, the common feature of traditional farming is the presence of spatial and temporal heterogeneity, often with complex plant age structure, mixed cropping, host-pathogen interactions and use of simple tools to plow and harvest crop (Chhetry \& Belbahri, 2009).

\section{RESEARCH APPROACH: MIXED}

Mixed methods research, provides strengths that offset the weaknesses of both quantitative and qualitative research (Creswell, 2006). The quantitative analysis is inadequate in understanding the context, or setting in which people talk. In addition, the voices of participants are not directly heard in quantitative studies. On the other hand, qualitative research is seen as deficient, because of the personal interpretations made by the researcher, the ensuing bias created by this, and the difficulty in generalizing findings to a large group, because of the limited number of participants studied.

Therefore, this study was designed to use mixed method. Both the textual data and numerical data were used, to analyze the findings and interpret the results. As the core premise of the definition is that, the combination of quantitative and qualitative approaches provides a better understanding of research problems, than either approach alone. Thus, in mixed research with the pragmatic approach, allows different methods and multiple ways for data collection and analysis (Creswell, 2006). For quantitative data collection, a survey method was used with the help of structured questionnaires, by employing the simple random sampling method. The goal of survey research, may be generalized to larger populations, or it may be intended to be transferable, that is, the "findings will be useful to others in similar situations, with similar research questions or issues of practice" (Cresswell, 2003). This method was used, to find out the level of understanding/perceptions of rural farmers, on the effects of climate change on agriculture. For qualitative data collection, ethnography was used. Ethnographic research allows collecting people's perceptions, on the certain theme discussed in the natural setting. People's actions and accounts are studied in everyday contexts (ibid.), and strong emphasis is given to "exploring the nature of a particular social phenomenon" (Hammersley \& Atkinson, 1995, as cited in Flick, 2009). I believe that, since ethnographic research helps to reveal the subjective knowledge, using an ethnographic approach has made this study more useful in exploring the rural people's knowledge level, on the use of different types of ITK to cope with the effects of $\mathrm{CC}$, drawn through personal experiences, which are subjective.

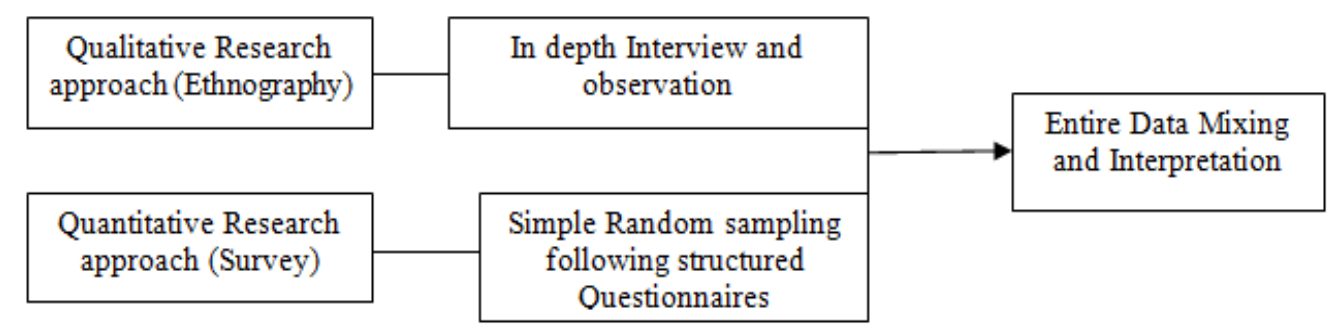

Figure 3: Flowchart of Research Approach

The ethnography produced ideas for policy recommendations and the content of a questionnaire. The survey data illuminated and validated, many of the things that, the ethnographer learned during participant observation. Those same survey data produced anomalies - things, that did not quite fit with the ethnographer's intuition. Ethnographic and survey 
data combined provide more insights than either does alone Adato (2008, p. 6).

\section{Sahartara - My Study Area}

Sahartara VDC is at about 6 hours of walking, from the district headquarter of Dolpa district-Dunai. It is surrounded by Mukot VDC in the east, Dunai in the west, Rukum district in the south and Lawan VDC in the north. The area of the VDC is 255 square kilometers, and the altitude ranges from about $2250 \mathrm{~m}-3804 \mathrm{~m}$ (LIBIRD, 2012). It is one of the VDCs, with an indigenous community, where the majority of the people are the indigenous ethnic group. They were about $90 \%$ of the people follow Buddhism. This VDC has $403 \mathrm{HH}$, out of which 353 are Magar and Gurung (Ethnic), while others are Thakuri and Dalits. The population of the VDC is 2114, among them 1091 are female (CBS, 2011). Sahartara is one of the richest VDC of Dolpa district, regarding cultivable land. About 811.14 hectares of land are suitable for cultivation. Agriculture is the principal occupation of the people, while they earn their living from Yarchagumba ${ }^{1}$ (Cordyceps) collection and trade, and livestock farming. Major crops of the VDC are Chino ${ }^{2}$, potato, maize, millet, bean, wheat and so forth. According to Local Adaptation Plan of Action (LAPA), prepared by LI BIRD in 2012, ward no 1, 6 and 7 of the VDC are extremely vulnerable, to the impacts of climate change, and remaining wards are highly susceptible. In a case of household (HH) vulnerability, $67 \mathrm{HH}$ is extremely sensitive, 102 high, 220 medium, and 14 low. Major climate change affects in the VDC: Drought, flood, human health, diseases in agriculture

\section{ANALYSIS AND DISCUSSION}

\section{Changes in Temperature}

The results from the household survey showed that, the temperature of their area is changing, moreover increasing, due to the expected increase in temperature, they started to cultivate chilly in their farmland, which was not produced until a few years ago, and they began to shift livestock's from flat land to Highland. It was around 8-10 years ago, they used to keep their livestock's close to their village, at higher altitude, but nowadays they have started to keep their livestock's in even higher altitude. They also said that, the snowmelt is at the rapid rate. According to respondents, before $10 / 15$ years ago, the snow on the land was stable, for 10-15 days in and around their village, but nowadays it melts within one week. It is one of the significant impacts of temperature rise. Due to a lesser retention time of snow, the result, the moisture of agriculture land is getting low. It further changes, during seed sowing time as the soil moisture does not retain till April/May. There is no doubt that, temperature has risen as recorded in Dunai Station. The data from DHM almost coincides with the peoples' version of the increase in temperature. While, people claim temperature has increased for 10-12 years, the data show the gradual rise in maximum temperature.

The data were taken from Department of Hydrology and Meteorology (DHM), for the nearest place to survey the site. The standard trend line is used for analysis. In the graph below, the trend Line equation is $\mathrm{Y}=-0.4411 \mathrm{x}+$ 24.646average yearly maximum and $\mathrm{Y}=0.2633 \mathrm{x}+8.3636$, for the minimum temperature of Dubai, which explains Minimum temperature is increasing and Maximum Temperature is decreasing, from 1991 to 2013, which is a sign of change in climate variability. 


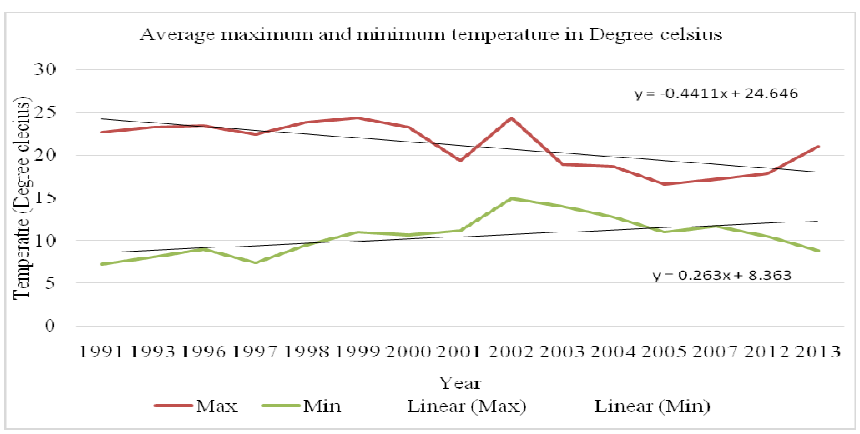

Figure 4. Correlation of Maximum and Minimum Temperature with Straight Line

\section{Error}

No information is available, about the number of precipitation gauges and temperature sensors, used in a station to record precipitation and temperature data. In addition, the exact location of these gauges and sensors is unknown. The lack of uniformity in rain gauges and temperature sensors can influence the quality of recorded data. DHM also mentions that, due to problems with data transmission by each station location, errors might be observed in the data. However, quality control is performed, but a $100 \%$ correction rate is not possible.

\section{Unpredicted Precipitation}

People had experienced not only decrement in the snowfall, but also lesser retention time. Their agriculture thrived on rainfall and snowfall. "Hiun Paryo Pus aba khaula khus" (snow came in January we eat happily) popularly told, among people, signified the importance of snowfall during December-January, while they too took it as a symbol for good cultivation in an upcoming year. "However, we do not receive snowfall during January these days. Some year, it is to late January-February, or even in February-March only." said women in the field. Meanwhile, they too indicated in rising temperature, causing lesser retention of snow. "Previously, snow fall of January used to retain till April is keeping the soil moist, making it suitable for cultivation," said 64 years old Dhana Bahadur Budha from Tarakot. However, now with the alteration in snowfall time, less volume of snow and higher temperature cause early melting of snow, resulting in loss of moisture in the soil. "This has the negative impact upon our agricultural system, we hardly find any moisture in the ground, while we plant in (April-May), which was opposite at least a decade ago," added Dhana Bahadur Bika from Riwa. The principal respondent and the locals involved in a discussion, respondents of our survey had the similar story to share. $88 \%$ of the interviewees experienced unpredicted rainfall. All of the respondents who experienced unpredicted rainfall informed that, they frequently observed such type of rain event. They too shared that, the average rate of precipitation is decreasing in recent days.

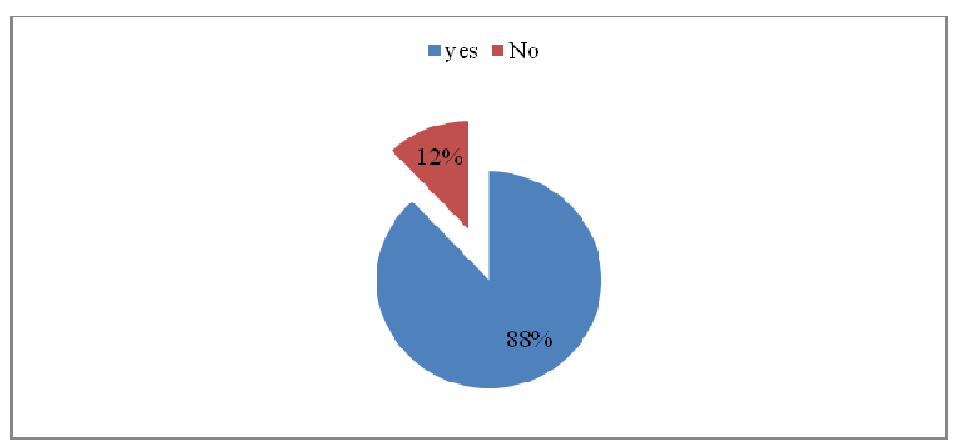

Figure 6: Perception on Unpredicted Rainfall 
We could not debunk the peoples' experience, but it is needed to be reinforced by the official data. We opted to look for precipitation data of Shahartara. However, Sahartara VDC has no station for the measurement of precipitation and temperature, hence, for the reference; data of precipitation and temperature were taken from the nearest station at Dunai. Supporting the peoples' perception and experience, the data showed the rainfall is altering each consecutive year,Dunai, Dolpa

$\mathbf{H}_{\mathbf{0}}$ : There is no trend in the series

$\mathbf{H}_{\mathbf{a}}$ : There is a trend in the series

Table 2: Mann Kendal Test Interpretation

\begin{tabular}{|l|c|}
\hline Kendall's tau & -0.507 \\
\hline & -206.000 \\
\hline Var (S) & 0.000 \\
\hline P-value (Two-tailed) & $<0.0001$ \\
\hline Alpha & 0.95 \\
\hline
\end{tabular}

The data were taken from DHM, from the nearest place to survey the site. Analysis of precipitation data was carried out, by using Mann Kendal Test, the value of p-value (Two-tailed) is calculated, using the exact method, as the computed p-value is lower than the significance level alpha $=0.95$, one should reject the null hypothesis $\mathrm{H}_{\mathrm{o}}$, and accept the alternative hypothesis $\mathrm{H}_{\mathrm{a}}$. The risk to reject the null hypothesis $\mathrm{H}_{\mathrm{o}}$ while it is true is lower than $0.01 \%$.
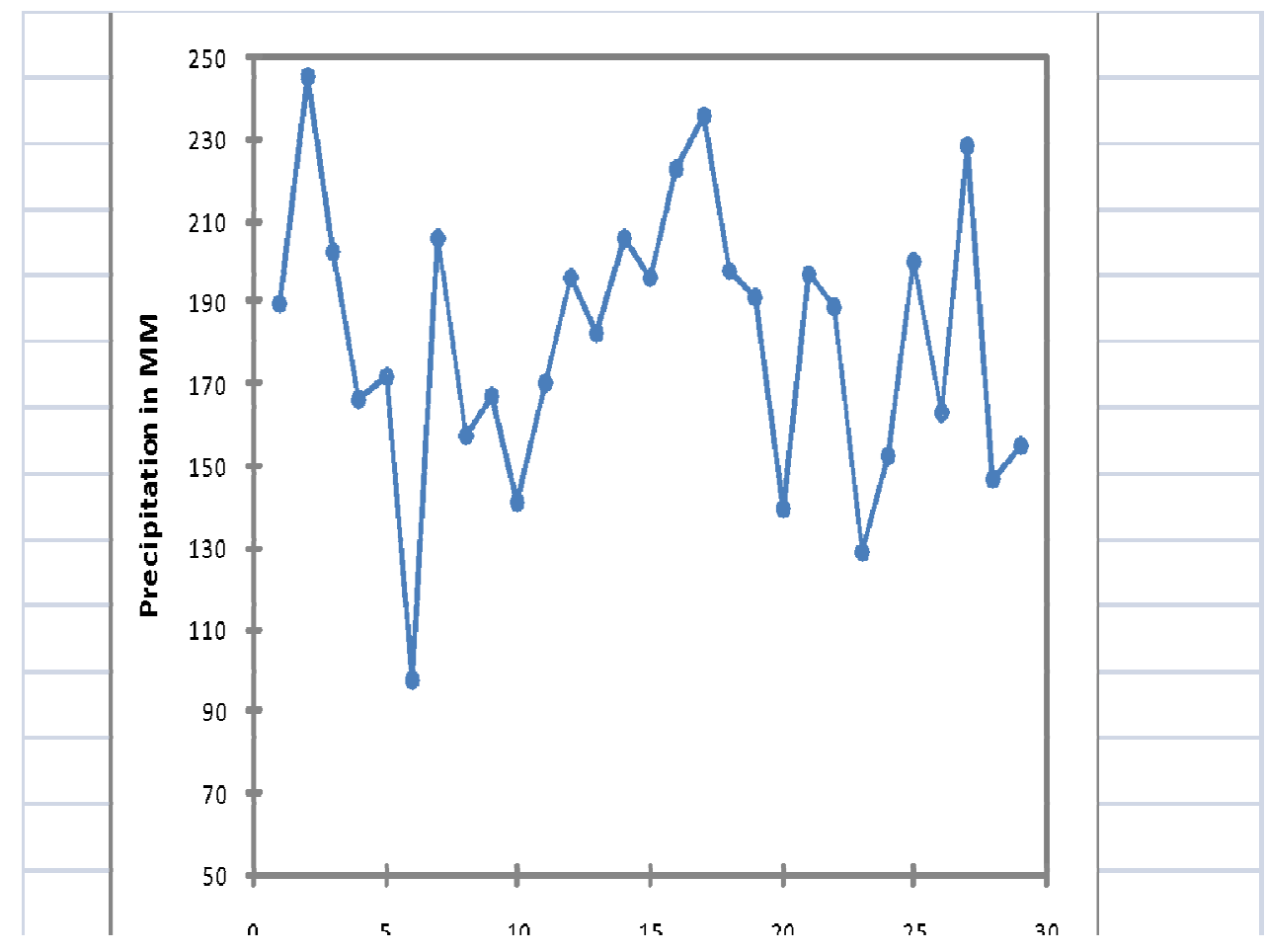

Figure 6: Precipitation at Dunai

According to the test, there is the trend in the series of rainfall data, about Dunai Station from 1984 to 2012 . The trend of precipitation is decreasing by $1.254 \mathrm{~mm}$ Sen's Slope every year, which is the sign of climate variability. Moreover, people noticed a delay in cultivation time, from 10-15 days, while they too have observed early maturing of crops. "We used to plant Sweet Buckwheat, during Shrawan first week of the year, while it has now shifted up to fifteen days later," said Dhana Bahadur Bika, from Riwa, "though we plant crop later than previous we harvest the crop almost at the same 
time like before."

By all the responses and the analysis of the DHM data, it was evident that, the temperature is varying in recent decades, while rainfall is erratic with very less amount of rainfall in winter. Thus, it can be concluded that, climate change is real and happening in the study area.

\section{Effects Climate Change}

We were in Sahartara ward number one (1) - the most vulnerable area to climate change, according to LAPA document. We looked over LAPA document and noted the shifts in the area. We had the least achievement in that, but there was no doubt that, the villagers must have found the change. My principal respondent in the ward Wangju Jhakri surely must have observed the change and vulnerability- we assumed. Though, he was busy on the field that, day inspecting millet in the field, he proposed me to walk along. We had talked much about the changing environment earlier. He had given us a brief history of the changes mostly about rainfall, snowfall, and temperature. He then spoke of the changes in agriculture system. In addition, respondents from other wards shared their plights of change in the agricultural sector system, due to changing an environment. Meanwhile, LAPA document had pointed out at the change, in agricultural practice and cropping time, we tried to look into the changes in the same manner. Talking to people in Tupatara, Tarakot and Riwa, people had told that, they had not brought any significant changes, but seen very striking changes, such as the shift in crop timing, early maturing of crops and an increase in compactness of the soil. We were very keen to see, if the people in the most vulnerable area have to say the same. To my surprise, we did not much find any difference in peoples' saying. Nor did the findings from the survey give the different glimpse.

\section{READYMADE REMEDY: INDIGENOUS TECHNOLOGY KNOWLEDGE (ITK)}

It was now evident that, agriculture is being threatened by the impacts of climate change. While, people had noticed the changing environment, they must have been adapting to these changes and finding solutions to their problemswe assumed. However, we were not completely right; rather people were following the same traditional way of farming, without any changes. Upon asking if they have employed any other method to ensure well being of their farm, the answer was rather negative. "We have done nothing to adapt to climate change," confirmed Dhana Bahadur Budha from Tarakot.

Albeit people said, they have done nothing for climate change adaptation, their practice indicated a different story. We looked into their practices minutely and tried to develop linkages, on how a particular practice could help in climate change adaptation. We were stunned by ours original interpretation of the traditional agricultural practice of people. Each practice assisted in combating climate change. Knowingly or unknowingly, people are adapting to the modification, and they have intense practices that will help them to fight against climate change, though, some external support might be required to internalize them. The practices, which at first looked very straightforward and easy to us, had a deeper relationship with the environment and hence helped people to adapt. The greatest challenge of agriculture in Sahartara, is the sloppy geographical structures. According to respondents view, we identified drought and landslide as the biggest problem, raised by climate change. Along with these pests attack and hail storm, are other major problems in the area. We thought their activity could be broadly categorized into two distinct sections, one is land management, and the other is food security. 


\section{Terrace System}

Most of the land has the slope greater than 30 degrees, in this condition the fields are prone to landslide, where chances have been raised even further due to climate change. However, thanks toterrace management practice of people. "We construct stone walls at slopes that give an impression of a terrace and make it easier for cultivation. And, it also reduces soil erosion, to retain soil moisture and soil fertility," said Dhana Bahadur Budha from Tarakot, agreed by Dhawa Chiring Jhankri from Tupatara and Dhana Bahadur Bika from Riwa. Most of the sloppy agriculture land of this area was maintained by terrace system.

For us, who have seenthe earthen terrace in most of the hilly regions of Nepal, seeing stonewall forming terrace was very interesting. Why stone? Why not with soil or cut hills to form terraces? "That sounds easier, compared to constructing a whole new wall out of those big huge looking stones," we contemplated. Are key respondents the only ones who are practicing such method? Nevertheless, from the survey, we came to know that, key respondents were not the only ones to practice the terrace system in such manner. All the farmers of the study area are managing terrace system in their farmland. Due to sloppy agricultural land, they raised terrace by making the stone wall to reduce soil erosion, to retain soil moisture and soil fertility.

Meanwhile, they also practiced a terrace relocation system in their farmland, to avoid weeds and to regain soil fertility from the terrace area once a year, while some relocated for up to 5 years time. "This allows restoring the fertility of the ground," said Purna Budha from Sahartara-3. Moreover, farmers also conserved grasses in the terrace and used it for their livestock. From the survey, it is found that, about $30 \%$ farmers relocate their terrace in the interval of two to three years, while remaining farmers transfer terrace in the range of five to six years.

One of the major reasons for using stones in the terrace is, for its sustainability and its ability to retain the pressure of steep slope as well. People believe that, if the use of stone terrace has no and lesser risk of soil erosion, during monsoon and during rainy times. The stones are arranged in lines across the slope, to form the walls and the permeable walls slow down the runoff, filter it, and spread the water over the field, thus enhancing water infiltration and reducing soil erosion (FAO, 2008). In hilly region, use of bio terrace and earthen terrace is unsustainable and may easily get damaged by rain, when the slope is greater than $20^{\circ}$ (ibid.). In addition, growth and development of plant species are slow. Hence, that cannot retain the eroded soil on the steep slope. The earthen and bio-terrace was not practiced by the farmers in that area. Li-Bird (2012), along with few other practices, has considered the stone wall terrace system as one of the replicable practices of Sahartara. Such stoned walls increase the biological activity and help to enhance the fertility of the soil (p. 35).

Besides the sustainability, farmers also used to make a stone terrace to manage those rocks, found in the farmland during its land preparation and land management. They use to conserve grasses and some crops, over the terrace to capture eroded soil that helps to maintain soil fertility and soil moisture. These buildings of stone terrace are an important adaptation practice to climate change, minimizing soil erosion and thereby, enhancing the productivity of the land.

\section{Tillage System}

All the farmers are practicing traditional tillage system, using one ox with the wooden plow. In contrast to this, people in lower Dolpa practice two ox tillage systems, due to the availability of flat land and lower gradient. However, due to steep sloppy and small agricultural land, they use one ox tillage system, to avoid high soil erosion and avoid heavy compaction of soil. They use Quercus tree (Kharsu) and Juglans (Okhar) tree, to make halo and fali, which is durable and 
reliable.

According to Glanz (1995), Tillage with the chisel plow (which is more like a halo of Nepal) that causes the least loss of organic matter (1720 kg/hectare), in 19 days as compared to another tillage system, such as Mouldbard plow +disc Harrow. Mouldbard plow, and disc harrow, which loses 4300, 2230 and $1840 \mathrm{~kg}$ of organic matter per hectare, in 19 days (as cited in FAO, n.d.). Though the chisel plowing also loses more organic matter, as compared to the direct seeding (860 $\mathrm{kg} / \mathrm{ha}$ in 19 days) still it is far better than those modern technologies, that tend to ease the cultivation practice of humans in the cost of the organic matter in the soil. Emissions of less organic matter, make the lands fertile, thereby increase the productivity and thus, act as an adaptation to climate change effects on agriculture.

It looked imperative from the perspective of adaptation to climate change. People in the region have hard times in managing the manure in the field. If they use the entire manure in the field in the single year, they are likely to threaten their agriculture system. Tillage with the "halo" (more like chisel plow) does not allow the loss of organic matter, which in return helps to retain fertility of the soil, increases infiltration and reduces evaporation. Hence, people refusing to use the most modern machinery, by emphasizing their tillage method have allowed them to maintain the soil organic matter, which not only supports fertility of the soil, preventing erosion, but also aids them in being less affected during drought, as drought are said to be triggered by climate change.

Moreover, there cannot be any argument about the wisdom of people, to use one ox to plow in the terraces. In the narrow and the sloppy agriculture field, one ox plow system applied by farmers directly, reduces the heavy soil erosion as well as effective tillage in every corner of the land. This system of tillage avoids and reduces intensive tillage, loosening soil and helpful to release soil nutrients, circulate water and air, within the soil and kill weeds for the growth and developments of crops.

Tillage is the mechanical, or physical process for increasing the crop production by manipulating soil, which helps to improve the soil environment for plants, to increase seed germination, suppressing weeds, root development at the lower level of soil, as well as increase soil infiltration, reduce evaporation and control soil erosion (Prihar, 1990). However, intensive tillage has detrimental effects on soil structure, which causes excessive breakdown of soil aggregates, leading to soil erosion, which is not the case in Sahartara. To mix manures and control growth of weeds, farmers plow their land before the seed is sown and again plowed, during the seed sowing time. That practice helps to loosen the compact soil and support proper germination of seed, as well as growth and development of crops.

\section{Crop Residue}

Farmers used to harvest crop, leaving crop residue on the ground and some parts above the ground (roots and some parts of the stem). The crop residue on the field is left for livestock feeding, during the winter season. The remaining crop residues under the ground are more important, to control soil erosion, maintain soil moisture, and improve soil quality.

We kept on thinking, how crop residue helps in the maintenance of soil fertility. The respondents would just answer the product, but not the process. Later, while going through the pieces of literature, we found, "crop residues are important agricultural tools used for soil and water conservation, improvement of physical properties of soil, improvement of water quality running of agricultural fields and increment of soil fertility" (Blevins and Frye, 1993).Moreover, an introduction of crop residue into the ground, offers the best means to restore carbon in agricultural soils (Regmi et al., 
2002). We thought how genius people are and how well they have understood the cycle of nature.

However, leaving the crop residue only would produce no significant result. In fact, tillage and residue management is helping to improve water infiltration and to reduce water losses from the soil surface, which has potential to improve crop yield and soil conditions in semi-arid tropics (Adekalu et al., 2007). The residue used in cultivation control soil erosion, by reducing rain drop impact on surface and decreasing water runoff rate, with increasing rainwater infiltration (Bartoon et al., 2004). It is also regarded as the mulching practice, that helps to retain soil moisture and ultimately adds organic matter back to the ground (Tengo \& Belfrage, 2004).

Looking at the agricultural practices and system for people in Sahartara, we thought no system is better than the self-sustaining system. Here, people have found out the ways to manage the resource properly and maintain harmony with nature. Moreover, leaving crop residue is equally important from Climate Change Adaptation Perspective, as well. While, such practices add fertility to the soil, it also prevents loss of soil through erosion and helps hold the soil in place, during fallow periods (Borron, 2006). It was incredible for me to see people have widely used their wisdom, to maintain the resources, to keep the environment intact and ensure their productivity. Since landslide and drought are significant impacts identified by the people, this particular practice will surely help them adapt to the issue, by preventing erosion and maintaining soil moisture.

\section{Fallow Land}

Farmers leave their land barren, without any crap for about five months, and cropresidue, reduces the soil erosion by capturing ground. They leave crop residues also for the soil fertility, as they think that these residues decompose naturally and helpful to gain soil fertility. Increasing temperature cause the moisture to evaporate, but crop residue will help the moisture to be retained in the soil. They also fire crops and other plant residues, over the land just before the seed sowing, to kill surface insects and pests. Few of them answered that, it is to regain the fertility, while a few said they have no hands to work in the field. We then started to analyze the data of agricultural land of Sahartara. It was wondering what percentage of arable land in Sahartara, is left barren. Then, would climate change not threaten food security, if they leave their land barren. People were reluctant to look into this part. They said, "This the regular practice that we have done. It is important to maintain the soil fertility."

There was no point in arguing with the people and worrying them with our hypothesis. However, again, we thought we should not be thinking of an issue from the single perspective alone. Though, food security is important, sustainability of the land is also equally important. In fact, it is more important in places where arable land is less abundant. However, it has to confirm if leaving the land barren would help in regaining the fertility of the soil. We doubted. We had seen the arid lands in Kathmandu, turning into playgrounds, making the soil compaction, losing fertility of the ground. We hoped the situation is different in Sahartara. "Well, who would turn these fields into the playground in this sloppy land?" we convinced ourselves.

Again, looking into the possibility of regaining the fertility of soil, according to FAO (n.d.) Tradition, a fallow period is used after a period of crop production to give the land some "rest" and to regenerate its original state of productivity. Usually, this is necessary for production system, that has drawn down the nutrient supply and altered the soil biota significantly, such as in the slash and burn methods or conventional tillage system.

It confirmed that, leaving the land barren could help in regaining the fertility of the soil. Again, considering the 
impact of climate change, maintaining the fertility of the soil is even more important to ensure the sustainability of the land. Moreover, having fertile soil with rich organic matter is an indication of the resilience, towards drought and landslide. "Hence, leaving the land barren also helps in adapting to climate change indirectly", we were convinced.

\section{Intercropping}

The results from the survey, interviews with the principal respondents and my observation concluded that, another noteworthy agricultural practice of Sahartara is intercropping. Though, the people practice both Single (Monoculture) cropping system and intercropping system, the intercropping is vital from the adaptation perspective. In Sahartara people cultivate only Sweet Buckwheat, Buck wheat, barley as single crop while, other plants are grown as the intercropping system. In an intercropping system, sub-crops are grown with major crop helps to get maximum production, as well as wise use and management of land. Well-chosen intercropping tends to increase productivity, as not every cover has the same nutrient and moisture needs at the same time. So, plants use resources more efficiently than, if only one crop is planted in the same area (Borron, 2006). Thus, the total productivity of all the crops grown in a zone is often higher than, if only one crop had been planted (Scialabba \& Hattam, 2003). The bean is one of the major subs- inter cropping plant cultivated with maize, Chino, and Potato. Besides this, Foxtail millet is intercropping with chino, and Bhango ${ }^{3}$ is intercropped with millet. Potato is also intercropped with corn and with chino. Talking about intercropping in Dhawa Chiring Jhankri from Tupatara said, "Our forefathers did the same, and we just followed. We do intercrop because it is suitable to crops. And we get at least one crop." Though, people know, intercropping has helped in improving their production and secured at least one crop as the agricultural product, and they are yet to understand this will have great significance to adapt Climate change.

However, the scientific world has already proven that, intercropping has a substantial positive impact on the agriculture of any place. Shetty et al., (1995) opines, "The principal reasons for farmers to intercrop are flexibility, profit maximization, risk minimization against crop failure, soil conservation and maintenance, weed control and balanced nutrition." It has been further supported by (Wanic, Kostrzewska, \& Jastrzebska, 2004) claiming, "Some intercrop species release allelopathic compounds which limit the occurrence of weed." It has been documented that, intercropping helps in reducing pest attack and pathogen infection, through greater biological control. As described by Berold, R., and Caine, C. (1998),

Intercropping of compatible plants also encourages biodiversity, by providing a habitat for a variety of beneficial insects and soil organisms that would not be present in a single crop environment. This biodiversity can in turn help to limit outbreaks of plant pests, by increasing the diversity or abundance of natural enemies, such as spiders or parasitic wasps. Increasing the complexity of the crop environment, through intercropping also limits the places where pests can find optimal foraging, or reproductive conditions.

The key reason behind this is, "intercropping provides an efficient utilization of environmental resources" (Eskandari and Ghanbari, 2009). Thus, the growth of weeds, depending on the availability of environmental resources, is decreased. Therefore, it can be concluded that, "Intercropping generate beneficial biological interactions between crops, increasing grain yield and stability, more efficient using available resources and reducing weed.” (Kadziuliene et al., 2009).

From this evidences, it is clear that, the intercropping done by people in Sahartara is helpful in ensuring 
agricultural production of their area. It is noteworthy that, citizens in Sahartara have posted increases in pest attack as one of their major problems, induced due to climate change (Li-Bird, 2012; fieldwork, 2014). Though, the pests have increased due to climatic reason, a diverse field containing more than one crops, offers much more opportunities to manage pests. Intercropping can distract pests, as the field does not provide the feast that, a monoculture does, and farmers often place certain plants around the borders of fields that repel pests (Ewel, 1986).Since, people do not use any pesticides, intercropping has helped them fight against the pest.

Moreover, crop intercropping has helped people to ensure at least one harvest, during the year preventing from food scarcity. In addition, this has helped in soil conservation activity. People are less likely to have the largest impact, due to landslide and soil erosion. It means, people will have their agricultural land available for cultivation in each year. It is evident to believe that, intercropping alone is not enough to fight, adapt with changing the environment. Nevertheless, it is surely a reliable measure to fight against the increasing pests and manage land, to prevent erosion and landslides that are being induced by climatic variation.

\section{Crop Rotation}

We were enlightened with numerous agricultural practices of Sahartara. Farmer practicing, crop rotations incorporate crops with different nutrient needs, allowing maximum use of soil nutrients (Borron, 2006). Amongst, the best practices of Sahartara, for us; at least, crop rotation is another replicable practice. But does it contribute to adaptation to climate change? The answer was obvious, yes! The crop rotation is vital in fragile lands like Sharatara, because if the same crop is planted every year, then soil fertility decrease and makes it even more vulnerable (Li-Bird, 2012, p. 35). Moreover, it is found that, Crop rotations additionally break weed and insect pest life cycles, reducing the interventions necessary for pest management (Borron, 2006).

From the junior classes, when the students are taught about the symbiosis examples of leguminous plants, we could see the real implication of it in Saharatara. People plant leguminous plants, such as beans (field peas, soybeans, or any other grain, beans) as sub crop or main crop. It is found that, "Leguminous crops in the rotation fix atmospheric nitrogen and bind it in the soil, increasing fertility and reducing the need for synthetic fertilizers, and the use of pesticides"(Fragstein, 1996).

However, the advantages of crop rotation are not limited to this only. According to (UNESC-APCAEM, 2007) crop rotation, it ensures higher diversity in plant production, along with the reduction in risk of pests and weed infestation. Reduction in risk of weed infestation is evident, as people have the least noted increase in weed as their problem. Moreover, they said that, they had not faced any problems due to weeds. It might be due to the effective application of crop rotation in Sahartara. Likewise, according to (Stoeva, 2014) crop rotation, it is crucial in agriculture as, Crop rotation helps in (1) greater distribution of channels, or bio pores created by the diverse roots (various forms, size, and depths). (2) Better distribution of water and nutrients through the soil profile.(3) Exploration for nutrients and water of the whole soil profile, by roots of many different plant species resulting in an optimal use of the available nutrients and water, (4) increased nitrogen fixation through individual plant-soil biota symbionts and improved balance of N/P/K, from both organic and mineral sources, increased humus formation (p. 9).

It is not of any misperception that, crop rotation is crucial for agriculture. And it is even more important in the place like Sahartara, where people have issues to manage enough fertilizer for crops and land is too fragile. 
Since, crop rotation does not enhance fragility of the land, people are Sahartara will have less fear of erosion or landslide, from one perspective. While, from the other perspective crop rotation has helped them to maintain the natural system, inhibiting the growth of pests and better development of the plants. We believe that, people are facing increment in the pest; the crop rotation has played its part to minimize the pest attack. Moreover, maintaining the soil fertility and rich organic matter, it prevents the use of additional chemical fertilizer; further aiding in land management. We firmly believe that, crop rotation is both mitigation and adaptation measure to climate change, as practiced by people of Sahartara, who are being threatened by landslide, erosion, erratic rainfall, and pest attack.

\section{Local Variety}

People practiced different types of crops together, to reduce the risk of crop loss and ensure some varieties that survive even if the crops fail completely, in some parts of the same land. Farmers grow different traditional varieties together to reduce the risk of crop loss and ensure some varieties, to survive even if the crops fail completely, in some parts of the community area.

Local landraces tend to offer the stability of more consistent yields, even in bad years (Stigter, Dawei, Onyewoty, Z, \& Xurong, 2005). It is because, traditional varieties or landraces are more genetically diverse than modern varieties, that they can better with stand environmental stress, such as lack of water or nutrients. In Southwest China, laboratory analysis has shown that, in Situ varieties has much higher genetic diversity than those same lines, held ex-situ for 30 years. The use of resilient landraces in particular plant breeding, shows real potential for adaptation, while, it also enhances incomes, biodiversity, and traditional knowledge. Farmers understand and appreciate the value of diversity - not only as a natural gene bank for resilient crop varieties, but also as an essential farming practice to reduce risk (IIED, 2011).We believe that, farmers of the study area have been cultivating traditional varieties of crop species that have the high resistant capacity to drought and can grow and develop in little water. Farmers never changed the crop varieties; they did not apply the new technologies, but they were practicing their traditional system, by adapting their traditional varieties from time to time.

\section{CONCLUSIONS}

The rural farmers did not know the term, Climate Change, but expressed that, they are feeling certain changes and seasonal changes in temperature. They are not aware of the phrase climate change, but they are knowledgeable enough to share that, climatic pattern is changing in recent times. In one way or another, there have been some effects of changing the climate, in their agricultural practices such as shifting of crop sowing time, by 15 to 30 days. However, Indigenous Technology Knowledge is playing the crucial role, in adaptation to climate change in agricultural practices. More specifically, ITK, which was adopted by the farmer, has been helping farmers cope with extreme climatic change in agriculture. Recent changes in climate have implications on agriculture, especially in the decrement of productivity. However, farmers ITK practices have contributed to adapt to climate change. Nevertheless, climate change has lots of uncertainties and unpredictability; ITK in fused with modern technology and can lead to the reliable coping mechanism to climate change, and helps to achieve sustainable development.

\section{IMPLICATIONS}

- We find people are aware of the changing environment, but have limited knowledge about the terminology of climate change. Moreover, Climate change has been more academic and scientific term, but the rural farmers are knowledgeable enough to share and express the changes in seasons, and its effect on agriculture. Thus, 
development agencies and government can emphasize the program related to climate change, bearing in the mind that, they are the sources of knowledge regarding climate change and its effect on agriculture. Through this research, it can be claimed that, rural farmers are not known to the scientific notion of climate change, but the effect brought by climate change in agriculture can be linked to a social phenomenon.

- People depend on rainfall and snowfall, for their cultivation, and they have avoided irrigation system so far. It has enhanced vulnerability in agriculture. We think the promotion of low-risk, high benefit irrigation techniques such as sprinkler irrigation and drip irrigation should be done to encourage better yield and zero erosion.

- It is apparent that Sahartara is rich in ITK, but ITK has not been promoted and documented, as it should be. So far, ITK is the only adaptation practice (though they are not doing it knowingly). Were solutely believe that ITK should be further promoted in the Sahartara. People can be made aware how their practices have helped them maintain the productivity and encourage continuing agriculture. It is even better if some other techniques are amalgamated with the ITK to promote ITK and sustain agriculture in Sahartara.

\section{ACKNOWLEDGEMENT}

We are deeply indebted for the support and guidance provided by Dr. Nani Raut, Associate Prof. Dr. Bal Chandra Luitel, Prof. Dr. Laya Upreti, Sajani Kandel, Yogendra Budha, Sabeena Karki and all our participants and Respondents. Without them, this research would not have been accomplished and want to dedicate this research work to the people of Dolpa, Nepal

\section{REFERENCES}

1. Abioye, A., Zaid, Y., \& Egberongbe, S. H. (2011). Documenting and disseminating agricultural indigenous knowledge for sustainable food security: The efforts of agricultural research libraries in Nigeria. Retrieved fromhttp://conference.ifla.org/ifla77

2. Adato, M. (2008). Integrating survey and ethnographic methods to evaluate conditional cash transfer programs (IFPRI Discussion Paper No. 00810). Rome: International Food Policy Research Institute.

3. Adekalu, K. O., Olorunfemi, I. A., \& Osunbitan, J. A. (2007). Grass mulching effect on infiltration, surface runoff andloss of three agricultural soils in Nigeria. Bioresource Technology, 98, 912-917.

4. Agbola, T., \& Ojeleye, D. (2007). Climate change and food crop production in Ibadan Nigeria. African Crop Science Conference, 8, 1423-1433.

5. Alam, M., \& Regmi, B. R. (2004). Adverse impacts of climate change in the development of Nepal: Integrating adaptation into policies and activities. Dhaka: Bangladesh Centre for Advanced Studies

6. Bartoon, A.P., Fullen, M.A., Mitcell, D.J., Hocking, T.J., Liu, L., Wu Bo, Z., Zheng, Y., \& Zia, Z.Y. (2004). Effect of soilconservation measure on soil conservationmeasure of soil erosion rate and crop productivity on subtropical Ultisols in Yunnan Province. China Agro- Ecosystem and Environment, 104, 343-357.

7. Blevins, R. L., \& Frye, W.W. (1993). Conservation tillage: An ecological approach to soil management. Adv. Agron., 51, 3376.

8. Borron, S. (2006). Building resilience for an unpredictable future: How organic agriculture can help farmers adapt to climate change. Rome: Food and Agriculture Organization of the United Nations. 
9. Branca, G., McCarthy, N., Lipper, L., \& Jolejole, C. M. (2011). Climate smart agriculture: A synthesis of Empirical evidence of food security and mitigation benefits from improved cropland management. Rome: FAO

10. Central Bureau of Statistics (CBS). (2011). Nepal living standard survey: Statistical year book. Kathmandu: Author.

11. Chhetry, K. G., \& Belbahri, L. (2009). Indigenous Pease and disease management practices in traditional farming systems in northeast India. A review. Journal of Plant Breeding and Crop Science, 28-38. Retrieved from http://www.academicjournals.org/jpbcs

12. Creswell, J. W. (2003). Research design: Qualitative, quantitative and mixed methods approach (2nd Ed.). New Delhi: Sage.

13. Creswell, J. W. (2006). Understanding mixed methods research. New Delhi: Sage.

14. Department of Hydrology and Meteorology (DHM). (2014). Temperature and precipitation data. Dunai, Dolpa: Author

15. Eskandari, H., \& A. Ghanbari, (2009). Intercropping of maize and cowpea as whole-crop forage: effect of different planting pattern on total dry matter production and maize forage quality. Notulae Botanica Horti Agrobotanici Cluj-Napoca., 37, 152155

16. European Commission Directorate-General for Agriculture. (2008). The fact sheet on climate change: The challenges for agriculture. European Commission Directorate-General for agriculture and rural development. Retrieved from http://ec.europa.eu/agriculture/index_en.htm

17. Ewel, J. (1986). Designing agricultural ecosystems in the humid tropics: Annual review of ecology and systematics. Retrieved from http://www.annualreviews.org/doi/pdf/10.1146/annurev.es.17.110186.001333

18. FAO. (n.d.) Practices that influence the amount of organic matter. Retrieved from http://www.fao.org/docrep/009/a0100e/a0100e07.htm

19. FAO. (2008). Sustainable land management technology: Konso Beach Terrace: Ethiopia: Author.

20. Flick, U. (2009) An introduction to qualitative research (4 ${ }^{\text {th }}$ Ed.). New Delhi: Sage.

21. Fragstein, P. (1996). Nutrient management in organic farming. In fundamentals of organic agriculture. Germany: IFOAM.

22. Franciso, H. A. (2008). Adaptation to climate change: Needs and opportunities in Southeast Asia. ASEAN Economic Bulletin, 25 (1), 7-19.

23. Ghimire, R. S. (2008). Environmental concern in Nepalese agriculture. Journal of Agriculture and Environment 9, 41-45.

24. Government of Nepal. (2011). National adaptation program of action (NAPA) to climate change. Kathmandu: Author.

25. Hammersley, M., \& Atkinson, P. (2007). Ethnography: Principles in practices ( $3^{\text {rd }}$ Ed.). New York: Routledge.

26. Intergovernmental Panel on Climate Change. (2007). Climate change 2007. London: Cambridge University Press.

27. International Centre for Integrated Mountain Development. (2007). Local knowledge of disaster preparedness: A literature review. Kathmandu: Author.

28. International Institute forEnvironment and Development [IIED]. (2011, October). Adapting agriculture with traditional knowledge. The International Institute for Environment and Development: Policy briefing. Retrieved from http://pubs.iied.org/pdfs/17111IIED.pdf

29. International Panel on Climate Change (IPCC). (2013). Summary to policy makers: Fifth Assessment Report of the Intergovernmental Panel on Climate change. London: Cambridge University Press.

30. International Panel on Climate Change (IPCC). (2014). Climate change 2014: Synthesis report. Geneva: Author. 
31. Kadziulieneet. al. (2009). Qualitative effects of pea and spring cereals intercrop in the organic farming systems. Agron Res, 7 (2), 606-611.

32. Khatiwada, S. (2011). Vulnerability assessment of indigenous people's livelihoods due to climate change in Darakh VDC of Kailali District (Unpublished Master dissertation). School of Environmental Science and Management, Pokhara University, Nepal.

33. Local Initiative for Biodiversity Research and Development (LI BIRD) (2012). Local adaptation plan of action, Sharatara VDC Dolpa. Pokhara: Author.

34. Malla, G. (2008). Climate Change and its Impact on Nepalese Agriculture. The Journal of Agriculture and Environment, 9 , $62-70$.

35. Maplecroft. (2011). Climate change risk atlas 2010: Vulnerable nations and safe havens. Retrieved from http://www.prevention web.net/English/professional/news/v.php?id=15379

36. Parajuli, D. R., \& Das, T. (2013). Indigenous knowledge and biodiversity: Interconnectedness for sustainable development International Journal of Scientific \& Technology Research, 2 (8), 2277-8616

37. Phuyal, N. (2013). Climate change vulnerability, impacts, and adaptation of agriculture in a mountain region of Western Nepal (Unpublished master dissertation). School of Science, Kathmandu University, Nepal.

38. Prihar, S. S. (1990). The impact of tillage on soil physical environment. International proceeding of Symposium for Soil Physics Applications under stress environment, January 22-26, 252-266.

39. Regmi, B., \& Adhikari, A. (2007). Human development report 2007: Climate change and human development - Risk and vulnerability in the warming world. Country case study-Nepal. New York: Development Program.

40. Regmi et al.(2002). Yield and soil fertility trends in 20 years rice, wheat experiment in Nepal.Soil Science Society, 66, 857867.

41. Shrestha, K., Shrestha, S. S., Rai, Y., \& Shrestha, N. M. (2008). Study of sustainable biodiversity conservation: Knowledge of indigenous communities in Nepal. Lalitpur: Institutional Strengthening Project National Foundation for Development of Indigenous Nationalities. Retrieved from http://www.forestrynepal.org/images/publications/Report.pdf

42. Stigter, C. J., Dawei, Z., Onyewoty, Z, L. O., \& Xurong, M. (2005). Using traditional methods and indigenous technologies for coping with climate variability. Climatic Change. Springer: Climate Change, 70 (2) 255-271. Retrieved fromwww.springerlink.com/(v5sfij45fokqmd55mvpopn45)/app/home/contribution.asp? referrer=parent \&backto=issue, 12,18;jo urnal,15,221;linking publication results, 1:100247,1

43. Stoeva, A. (2014). Plant Protection in organic farming. Joint Bachelor course in organic agriculture. Agricultural UniversityPlovdiv. Retrieved from https://www.fibl.org/fileadmin/documents/sub/scopes/06-scopes-PlantProtection_Final.pdf

44. Tengo, M., \& Belfrage, K. (2004). Local management practices for dealing with change and uncertainty: A cross-scale comparison of cases in Sweden and Tanzania. Ecology and Society, 9 (3). Retrieved from www.ecologyandsociety.org/vol9/iss3/art4

45. Timsina, P. N. (2011). Climate change phenomenon in Nepal. ANPF \& SAAPE. Retrieved fromhttp://www.ngofederation.org/index.php?option=com_content\&view=article \&id=101:climate-change-phenomenon-innepal\&catid=36:president-blog\&Itemid $=27$

46. Tiwari, K.R., Awasthi, K.D., Balla, M.K., \& Sitaula, B.K. (2010). Local people's perception of climate change, its impact and adaptation practices in Himalaya to Terai regions of Nepal. Pokhara, Nepal: Institute of Forestry. 
47. UNESC-APCAEM. (2007). Development of conservation agriculture in Vietnam. Zhengzhou: United Nations-Economic and Social Commission for Asia and the Pacific.

48. Wanic, M., Kostrzewska, M., \& Jastrzebska, M. (2004). The role of intercrop of sowing in weed controls for spring barely in cereal crop rotation. Fragm Agron, 1, 85-102. 